\title{
朝鮮の住宅「雲鳥楼」における懸板・家系継承・祭祀 からみた住まいの場所の究明 \\ 一「住まう」ことの場所論的研究（その 1$)-$ \\ A STUDY ON THE PLACE OF DWELLING SEEN FROM BOARDS, FAMILY SUCCESSIONS AND RELIGIOUS RITES OF "UNJORU” \\ IN THE JOSEON DYNASTY \\ - Topological theory of place on dwelling (Part 1) -
}

金 秉 顛*, 西垣 安比古**

\section{Byoungjin KIM and Yasuhiko NISHIGAKI}

\begin{abstract}
This paper considers the topological meaning of people's lifestyles on traditional "UNJORU” houses in the Joseon Dynasty. Up till now, there have been many discussions about traditional houses in Joseon, which mainly focused on the use of space. However, as human's living places in daily life, the home is not just a possession which can be dissected according to principles of form. Moreover, the home cannot be addressed in a logical form of spacious constitution and applications of physical theory. The home is the place where human beings experience relations among themselves and with the environment around them. Discussions of this paper were mostly based on the records of dwelling and lifestyle from this perspective. Besides, records of these lifestyles, such as the boards (tablets), the family successions and the religious rites at that time, were studied. As a result, the master room of "UNJORU', the place for a head of a family, was expressed as the center of the house by a head of a family recognizing his own existence and positioning. Furthermore, the culture of life which consists of more various elements will be discussed in the next study.
\end{abstract}

Keywords : Joseon Dynasty, UNJORU, Dwelling, Place 朝鮮時代, 雲鳥楼, 住まい, 場所

\section{1. 序論}

\section{1-1. 研究の背景と目的}

朝鮮時代の伝統住宅は舎廊棟、内棟、祠堂などが集まって一つの 全体が形成される。このため従来の研究ではこれら個別建物につい ての精細な研究が行われてきた。あるいは、舎廊棟、内棟を男女有 別という儒教思想で説明するというような観念的枠組を先行させる 研究が多くを占めてきた。しかし、朝鮮時代後期には日常生活を窥 うことができる記録があり、ここではそれらの史料を通して具体的 な日常生活の様相を明らかにし、そこに表れる住まいの場所の意味 を究明することを目的とする。つまり、本研究は、住まいの場所を 人間と住居のかかわりの中に捉えることを目指している。

\section{1-2. 既往研究}

雲鳥楼注 1) に関連する総合的な調査は、1987 年韓国「国立民俗博 物館」注2) と 2007 年韓国「文化財庁」注3)によって報告されている。 これらは雲鳥楼の文化遺産を体系的に分類しており、雲鳥楼を研究 するための基礎資料として幅広く活用されている。一方、1968 年す でに金正基は、建築学的な立場から雲鳥楼の建築的意味と性格につ いて、『求禮雲鳥楼』注 4) としてまとめている。
雲鳥楼に関する建築分野の論文としては「求禮雲鳥楼の造営に関 する史料的考察」注 5) と「求禮雲鳥楼の住宅史研究」注 6 そして「求 禮雲鳥楼の創建と変遷に関する研究」注 7) がある上の研究は日記と 建築図などの記録資料をもとに分析したもので、雲鳥楼の創建背景 と現在に至るまでの規模の変化、空間利用の変遷過程をまとめてい る。

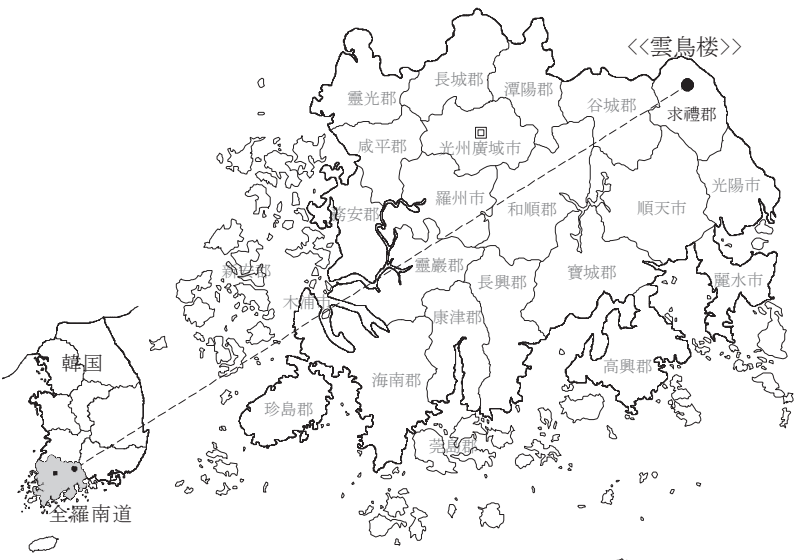

$\mathbb{8}$

図 1 研究対象である雲鳥楼の位置㘠

\footnotetext{
$*$ 京都大学大学院人間 $\cdot$ 環境学研究科 博士後期課程 $\cdot$ 工修 Ph. D. Candidates, Graduate School of Human and Environmental Studies, Kyoto Univ., M. Eng.

** 京都大学大学院人間・環境学研究科 教授 $\cdot$ 工博

Prof., Graduate School of Human and Environmental Studies, Kyoto Univ., Ph. D.
} 
また、雲鳥楼の建築空間に関する論文としては「全羅求禮五美洞 家圖を通して見る雲鳥楼の空間構成に関する研究」注8) がある。この 論文は雲鳥楼に関する書画類に基づいて、絵図表現における視点の 問題に着目し、そこから住居の空間構成を解釈している。これら以 外にも、生活史研究としては「求禮柳氏生活日記 “紀語” を通じて 見た近代生活の一面」注9)、造景史研究としては「求禮雲鳥楼庭園に 関する研究」注 10)、「求禮雲鳥楼の造営思想に関寸る研究」注 11) そし て、地理学研究としては「日記を通じて見た韓末一日本統治時代兩 班小地主の活動空間」注 12) がある。これら以外にも、日記注13) を対象 に進められた各分野の研究は注 ${ }^{14)}$ 、本研究を進める可能性を与えて くれた点において重要である。

以上を概観して、雲鳥楼に関寸る既往研究は、建物の規模変化や 造営過程あるいは中国の朱子家禮に起因した住宅の空間構成原理の みを論じていることが分かる。これに対して本研究は、日常生活に 着目し、生活相に表われた場所的意味を明らかにすることを目指し ており、この点で既往研究とは異なる独自の視点を提供するもので ある。

\section{2. 雲鳥楼}

\section{2-1. 雲鳥楼の立地と建築}

雲鳥楼の立地は、風水地理的背景を持つとされ 注 15$)$ 、明堂の形勢 を維持しているという。村の後側には智異山老姑壇が南側稜線を成 しており、村の前にはこれらの間に流れる溪川によって形成された 広い沖積平野が開かれている。また、蟾津江が西から東に流れてお り、背山臨水の典型的な立地環境を備えている。

そして、村の前方、蟾津江の向こう側には、案山の役割をする五 峯山があり、さらに遠方、南側には鷄足山があり、朱雀の役割を果 たしている。最後に東側には王甑峰が、西側には天王峰があり、こ れらの山は左右の青龍・白虎とされる注16) (図 3 参照)。

雲鳥楼は昔から風水地理的明堂とされ、世 間の耳目を集めて来た。 李重煥の『擇里志』注 17)では朝鮮で一番住みやすい所の一つとして 全南求禮の九萬注 18$)$ をあげており、一方、1931 年朝鮮総督府が刊行 した『朝鮮の風水』注 $\left.{ }^{19}\right)$ にも記載がある。また、柳氏家の文書であ る日記には、雲鳥楼の明堂に興味をもつ者の訪問や、周辺の人々の 転出入に関する記録があり、これも同じ脈絡で把握できる。

雲鳥楼の建築背景は、創建主柳爾胄 （1726〜1797）の履歴を通じて確認できる。 『朝鮮王朝実録』によると彼は 17 歳で漢 陽に上京し、28 歳の頃 $(1753$ 年英祖 29 年)武科に合格し、多くの武官職を歴任し た主 20)。そして、柳爾甾の行跡を記録し た『三水行狀実録』注 21 によると、1774 年に三水流配から戻り、親戚とともに雲 鳥楼を建てた (1776 年) という。

ゆえに、柳爾胄は武官職による築城工 事の経験を通じて建築造営能力があり、 敷地として全羅南道求禮を選んだ理由も、 李重煥『擇里志』が言うように水利の条 件が一番いいという点、そして 1771 年に 柳爾冒が郡守に在職した樂安（全羅南道 順天) が求禮と隣接する地域という点に 求めることができる。

雲鳥楼は、大舎廊棟を中心に 3 つの棟、 24 間の東西廊棟、そして祠堂で構成され る。舎廊棟は家長の居所である外舎 (隨分 室、雲鳥楼、足閒亭、二肯齋) と長子の居 所である中外舎 (湛樂窩、歸來亭)そして、 老年期を過ごすための下外舎 (弄月軒)で 構成され、舎廊の機能が細分化されてい ることを特徴とする。

創建当初から現在までを見れば規模に おいて大きな変化注 22 があったことが分 かる。まず、1804 年前後頃、東西廊と楼 を撤去して一次縮小され、1860 年代に 東・西行廊と東足砧室などが部分撤去さ れ二次縮小。そして、1900 年初頭と 1910 年代中盤には弄月軒と中外舎および各種 夾門が撤去され三次縮小された結果、現 


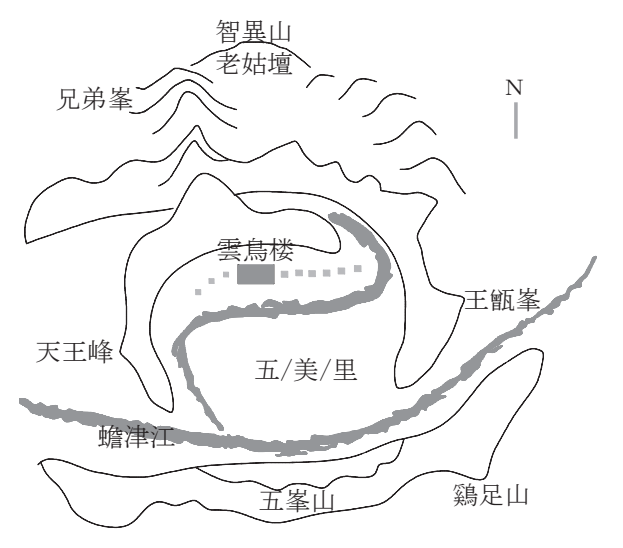

図 3 雲鳥楼の風水地理

在に至る。したがって、初期の品字型注 23)の空間配置については正 確に知ることはできない。このような内容をまとめて現在の雲鳥楼 実測平面注 24) と「五美洞瓦家舊時全圖」注 25) を重ねて、各室の位置、 規模と名称を平面図として作成した (図 2 参照)。

\section{2-2. 雲鳥楼の家内史料}

求禮郡土旨面五美洞柳氏家の家内史料として、生活用品（壁飾り、 屏風）、家屋図、懸板、影幀など扁額類 21 点、文書類 42 点、絵画類 11 点が所蔵されている。このような史料は、生活に関する意識や趣 向を表しており、本研究にとって重要な意味を持つ。ここではまず 懸板注 26) と日記を取りあげることとする。

懸板は宮殿、門等の個別建物の軒の下に掛ける、建物の名称を書 いた扁額である。伝統建築において懸板は単純に建物の名称を現わ すばかりではなく、建物の用途・機能と造形目的、そして居住者の 文化水準なども表わしており、当時の生活を見るうえで重要な史料 である。また、懸板の位置的関係は、雲鳥楼の空間構成を知るうえ で重要な意味をもつと思われる。

さらに、文書類中に日記があり、創建主柳爾胄の宗孫である柳濟 陽の『是言』注 27) と彼の孫である柳瑩業の『紀語』注 28) が残されてい る。時期的に連続したもので、『是言』は 1851 年から 1922 年まで、 『紀語』は 1898 年から 1936 年までで、両者を合わせば前後 86 年間 の周辺事情が書かれている。この二種類の日記は、毎日の生活につ いて記録したもので、備忘録の性格を持っている。これらは記録者 が男性であり、このため男性を中心とした内容になっている。女性 の視点からの日常生活の見方についてはほぼ欠落しており、そこに 史料としての限界があることは明記しておかなければならない。

\section{3. 懸板の位置関係と舎廊房}

懸板は、それを掛ける部屋の名称を示寸ものであるが同時にその 位置と内容によって住まいの諸場所に意味を付与し、あるいは、そ の性格を表わす。したがって、柳氏家屋の懸板の位置と内容を通じ、 雲鳥楼の各場所の意味や性格が把握できる。特に、雲鳥楼の懸板は、 ほとんどが柳氏家当主の別號であるという点で特異である(表 1 参 照)。柳氏家においての別號は、直系の父親あるいは祖父がつけてお り注 29)、そこに家系継承への強い志向が窥える。つまり、当主と懸 板の掛けられた場所との深いつながりを示唆していることになる。
表 1 柳氏家系図と別號

\begin{tabular}{c|c|c}
\hline \multicolumn{2}{|c|}{ 柳氏家の家系図 } & 別號 \\
\hline 1 代 & 柳爾胄 $(1726 \sim 1797)$ & 歸晚窩 \\
\hline 2 代 & 柳德浩 $(1757 \sim 1815)$ & 隨分室 \\
\hline 3 代 & 柳 億 $(1796 \sim 1852)$ & 圓石 (足閒亭) \\
\hline 4 代 & 柳見龍 $(1817 \sim 1851)$ & 弄月軒 \\
\hline 5 代 & 柳濟陽 $(1846 \sim 1922)$ & 二山 \\
\hline 6 代 & 柳永桓 $(1869 \sim 1892)$ & - \\
\hline 7 代 & 柳瑩業 $(1886 \sim 1944)$ & 五石 \\
\hline 8 代 & 柳曾呚 $(1906 \sim 1971)$ & 笑石 \\
\hline
\end{tabular}

本研究の対象である雲鳥楼では主に舎廊棟を中心に懸板が掛けら れており、製作背景は次のように区分される。柳爾胄（1726-1797） の友人であり同僚である尹師國 (1728-1769) が歸晚窩、二肯齋、湛樂 窩の懸板の作者である。柳爾冒の三代孫である柳億 (1796-1852)、そ して 5 代孫である柳濟陽 (1846-1922) とそれぞれ交友があった李翊 會 (1767-1811) が隨分室、足閒亭、雲鳥楼、歸來亭の懸板の作者であ り注 30)、閔泳喆 (18??-?) が二山楼の作者である注 31$)$ 。彼らは書道で一 家を成した人物で、彼らと友誼を交わした柳爾胄と柳億、そして柳 濟陽も書画に対する造詣が深かった。

表 2 交友関係による懸板の製作

\begin{tabular}{|c|c|c|}
\hline \multicolumn{2}{|c|}{ 交友関係 } & 懸板名 \\
\hline 柳爾胄 & $\begin{array}{c}\text { 尹師國 } \\
(1728-1769)\end{array}$ & 歸晚窩、湛樂窩、二肯齋 \\
\hline 柳 億 & $\begin{array}{c}\text { 李翊會 } \\
(1767-1811)\end{array}$ & 足閒亭、雲鳥楼、歸來亭、隨分室 \\
\hline 柳濟陽 & $\begin{array}{c}\text { 閔泳喆 } \\
(18 ? ?-?)\end{array}$ & 二山楼 \\
\hline
\end{tabular}

雲鳥楼の舎廊棟には楼と大庁、そして三ヶ所の房があり、それぞ れに懸板が掛けられている。尹師國によって製作された懸板、歸晚 窩は雲鳥楼の舎廊房にあり、それは家長が起居するところである。 湛樂窩は家系の代を引き継ぐ長子の起居する部屋である。そして、 二肯齋は雲鳥楼の書斎であり、家長や長子が学問修養するための場 所である。これら三つの場所の特徴は、すべて房という点である。 一方、李翊會によって足閒亭、雲鳥楼、歸來亭、隨分室の懸板が製 作されたが、これらの懸板は、隨分室 (舎廊房)を除いて雲鳥楼を訪 ねて来る客を接待する場所である板間(マル)に掛けられているとい う点で尹師國の場合とは異なっている注 32 。

ただ、隨分室の懸板は柳爾胄が掛けた懸板である歸晚窩と重複し て雲鳥楼の舎廊房に掛けられているという点で、他の懸板が板間に 掛けられたのとは差異を見せる。このことの意味を明らかにするた めにまず、柳爾胄が雲鳥楼に卜居して以降、最初に懸板を掛けた場 所が房であったという点に着目したい。歸晚窩は、家長が起居する ところで、一般的にも重視される部屋であるが、柳爾胄自身が自分 の別號注 ${ }^{33)}$ としたという点で特別に意味をもつ場所として位置づけ られていたことが窺える。また、歸晚は「夜に帰る」という意味で あり、柳爾胄が「老年を迎えて本来あるべき場所へ帰る」という意 味に解釈できる。すなわち、柳爾胄において舎廊房の歸晚窩は、彼 の住まうべき本来の場所を占めるという意味をもつことを示唆して いる。一方、隨分室は家長が起居する房としての意味をもつととも 
に彼の父親の別號であり、柳億にとっては家系継承の核となる 場所 として位置づけられていたことが窥える。隨分は「分に随う」とい う意味であり、柳億は舎廊房の隨分室において、家系の継承に沿つ て、社会的な規に随って生きることを重視していたことが窅え、そ のことを父親の別號を用いて披瀝しているといえる。

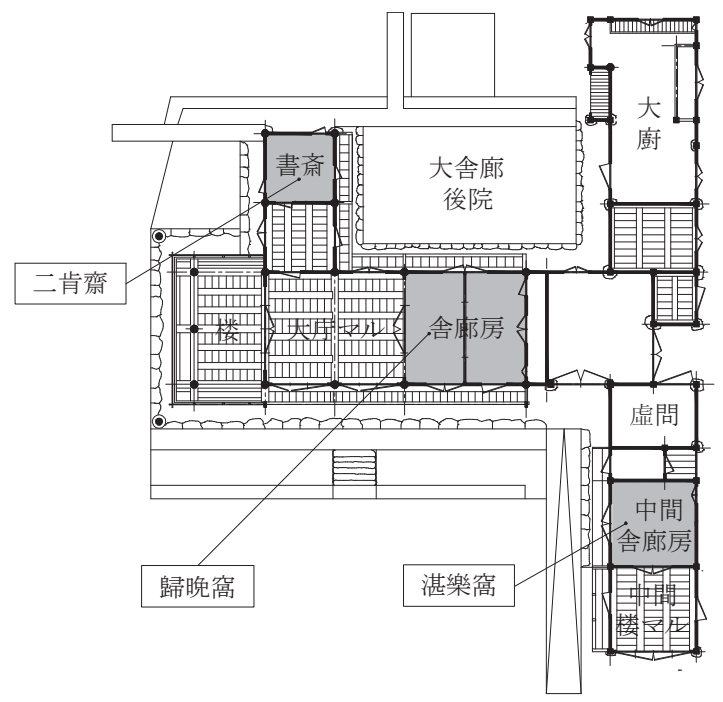

図 4 尹師國によって製作された懸板の位置

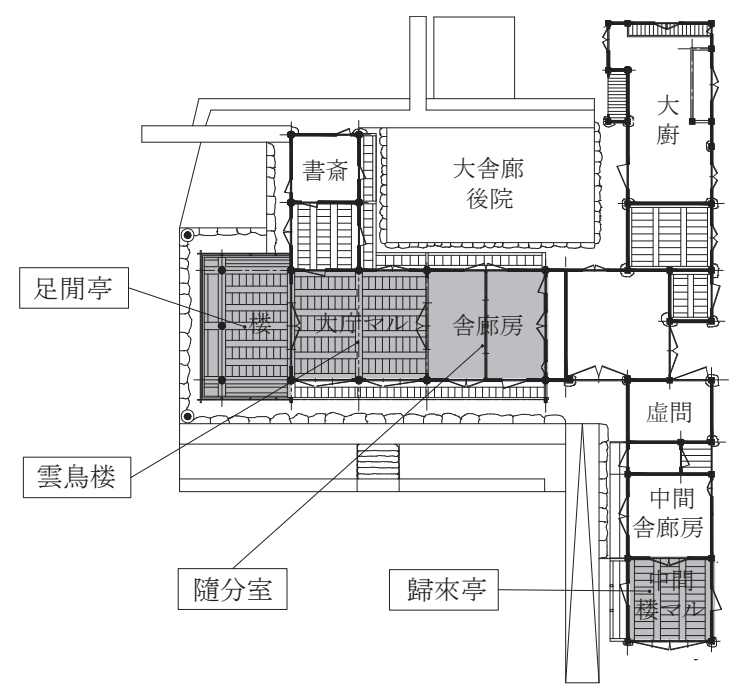

図 5 李翊會によって製作された懸板の位置

以下に、懸板の掛けられた位置についても考察する。柳爾胄が 卜 居に際して懸板を掛けたのは、歸晚窝を中心に二肯齋と湛樂窝であ り、それらは彼の起居すべき場所であった。一方、柳億は隨分室と ともに板間である足閒亭、雲鳥楼、歸來亭に懸板を掛けており、そ れらは主に儀礼を行い、あるいは賓客を接待する場所であった。す なわち、柳億は板間に懸板を掛けたという点で、柳爾冒とは異なる。

この差異については、以下で意味を探る。

まず、柳爾胄が懸板を掛けた舎廊房は、彼自身が起居するところ である。一方、柳億が懸板を掛けた板間は一般的に、社会的で開放 された場所に該当する。つまり、柳爾甾は房を中心として個人に固 有な場所に、柳億は板間を中心として社会的な場所に㲘板を掛けた
ことが知れる。また、柳億が舎廊房に重複して懸板を掛けたのは、 先祖の起居した場所に家長としての自分も起居するという意思の表 現といえる。すなわち、舎廊房は家系継承の中心であるといえよう。

以上、懸板の意味と位置からみた雲鳥楼の舎廊房(歸晚窩、隨分室) は、柳爾冒と柳億の双方にとって住まいの中心、寸なわち雲鳥楼の 中心であるということが明らかになった。

\section{4. 家系継承による場所的表現}

朝鮮時代後期の家族は、家系継承において長子優待が定着し、住 居空間もそれに対応するように形成された。長子優待とは 注 ${ }^{34)}$ 原則 的に長子が祭祀権を継承し、財産の中で一番重要な家を相続するこ とを意味する。当時の朝鮮社会において長子優待は、家門の永続を 象徵するものとして上流階級、特に宗家の場合、さらに顕著に現れ た。そして、長子につながる子孫は代々、同じ家で居住する。

朝鮮時代の家系継承は、16 世紀中半から男子中心の親族集団の組 織化が必要になったことを発端として形成された。継承方法は地域 によって大きく 4 つの類型があり、東南型 (隠居型)、西部型 (終身型)、 濟州型 (独立型)、咸鏡道型 (再州型) に分類される注 ${ }^{35}$ )。継承する内 容は、大きく財産権と祭祀権の二者にわけられる。朝鮮の家族制度 は、朱子学を受け入れる前から「家父長的家族制度」存立の素地が あり注 ${ }^{36)}$ 、構造的に「家父長的大家族制度」を志向した 注 37 。支配階 層においても儒教理念を生活化しようとする姿勢は、祖先崇帱と家 系継承によって一層強化された。そのため朝鮮中後期に至ると家門 と親族組織の具体的象徵である宗家の祠堂が持つ意味は深くなった。 家系継承の最高の権利として、家内の象徵的権威である祭祀権を中 心に家父長制が絶対的意味を持つようになる。すなわち、一般的に 長子が舎廊棟の大舎廊房を占有することは、実質的な家系継承が成 り立ったことを示しており、家長になることを意味する。このよう な点に着目し、『是言』と『紀語』を通じ、柳氏家屋の諸場所の意味 を明らかにする。

柳濟陽は 1851 年、彼が 6 歳の頃、父親を失うことになる。それ以 降、約 16 年間、季父 (父親の弟) が雲鳥楼の家事を管理したが、1868 年、22 歳の時から柳濟陽が本格的に継承することになった。

$\bigcirc$ 柳濟陽『是言』 1 巻、 1851 年 (辛亥)

残念ながら私は生まれて 6 年で一人になった。亡くなった父 親の姿を明らかには覚えておらず、ぼんやりと顔と華やかな 髪の毛、大きい背中を覚えているだけである 注38)。

$\bigcirc$ 柳濟陽『是言』 1 巻、1862 年 (壬戍)

二肯齋で詩を暗誦した。師も友人もなく、科挙の試験勉強を して、たまに近体詩を作ったりした。漢魏唐宋の多くの大家 の詩を鑑賞した。辛西年春に外舎廊前の東西の長い行廊棟二 十間を修造して、東西の四間は撤去した。秋に完成して、家 事は季父が管理した注39)

$\bigcirc$ 柳濟陽『是言』 1 巻、1868 年 (戊辰)

秋に隨分室で暮らすようになり、家事を管理し始めた。隨分 室は曾祖父の別號だった注40)。

これらの記録は、彼が 6 歳の時から長子優待権を持っていたが、 祭祀権と家事権が彼の季父にあったという点で家長権の行使ができ 
なかったことを示している。すなわち、1868 年から隨分室 (舎廊房) に起居することになり、家事権とともに祭祀権が付与され、今まで (1868 年)できなかった祭祀と家事の管理など家長の権利を行使す るようになったのである。

\section{$\bigcirc$ 柳濟陽『是言』 1 巻、1869 年(己巳)} 祠堂で茶礼を執り行って、正月の朝に高祖、曾祖、祖父とそ の母、そして亡くなった父母の神主 注 ${ }^{41}$ ) そそれぞれ合櫝 (夫 婦の神主を一つの䍜の中に入れる) した。父親の神主を今ま で作ることができなかった。辛亥年秋に父親が亡くなって葬 式を行なう日、六歳の幼い年に祭祀を行うことができなくて、 大変慌ただしい状況で執事するにも礼に慣れていなかった ことは嘆かわしい。世間の状況がだんだん悪くなってかれこ れ時間を過ごしたから、不肖の子が祭祀と名節の日に紙榜を 付けて祭祀を執り行なうのを残念に思う。真心から神主を遅 れて作ったことを自責した。礼をつくすことにおいて、早晚 はないのに注 42)。

すなわち、朝鮮時代の社会的規範であった家父長制度も、長子が 若年などの理由で祭祀を執り行えない場合、家の中心となる舎廊房 にも起居せず、家長としての資格を得られないことが分かる。

柳濟陽は 1868 年から隨分室を占有した後、1917 年までの約 65 年 間、雲鳥楼の家長として家事を担当するようになる。この年、柳濟 陽から柳瑩業へ家系継承が行われる注 43 。

○柳濟陽『是言』39 巻、1917 年 (丁巳) 1 月 24 日 十一年の間、門を鎖したから目に見えるものはすべて大きく 変わっている。〈中略〉家の孫がだんだん成長して部屋を掃除 した。私の志通りではなかったが、禁じなかった。丁巳年 24 日にオンドルを直して隨分室に入った 注 44 )。

柳瑩業は 30 代から年老いた祖父の代わりに実質的な家事を引き 継いで家長になる。また、自ら執り行った祭祀に対する頻繁な記録 の登場も家長権を行使したことの根拠になる。約 14 年間、雲鳥楼の 家事を担当した柳瑩業は、47 歳になると、地域有志としての社会活 動が増える一方、家内の大小事の中で一部を、長男である柳曽呚に 委任する。この際、隨分室が家系継承の行なわれる場所になり、祭 祀権も長男に委任されることになる。家系継承以降、柳瑩業の長男 が祭祀主になり、祭祀を行なうなど実質的な家長権が委任されたと いうことは下の記録で分かる。

○柳瑩業『紀語』34 巻、1932 年 (壬申) 1 月 1 日 歲拜 (セべ) 注 ${ }^{45}$ )の場所には、大舎廊隨分室を臨時に用いた。 私が去年冬から歸來亭で暮しているからである 注 ${ }^{46)}$

○柳瑩業『紀語』35 巻、1933 年(癸西) 1 月 1 日 朝早く祠堂に入って礼をして、曽敉に茶禮を執り行なわせる ようにした注 47)。

柳瑩業『紀語』 35 巻、1933 年(癸西) 1 月 14 日 曾祖母鎮川宋氏の祭祀の日である。〈中略〉曽敉を雲川に送っ て墓参りさせた注 ${ }^{48)}$ 。
以上から柳氏家の家系継承には、必ず当主の舎廊房での起居が伴 うことが分かる。すなわち、雲鳥楼の舎廊房は、社会的規範と家父 長制度に従って祭祀と家事権を行使する中心であったことになる。

\section{5. 祭祀空間を用いた場所的表現}

『朱子家禮』を原則にした朝鮮時代の祭祀は、以下の表に示寸通 りであった (表 3 参照)。祠堂祭は祠堂の前で、家祭は正寝の堂が儀 礼の中心空間になる。万一、祠堂がない場合は内棟の正寢や大庁で 祭祀が行なわれるのが一般的である。

表 3 朱子家禮による祭祀の種類と場所

\begin{tabular}{|c|c|c|c|}
\hline 種類 & 対象 & 時期 & 場所 \\
\hline 四時祭 & 高·曾·祖考泚注 49)、考妣 & $2 \cdot 5 \cdot 8 \cdot 11$ 月 & 正寝 \\
\hline 初祖祭 & 始祖 & 冬至 & 祠堂 \\
\hline 先祖祭 & 始祖以下、高祖以上 & 立春 & 祠堂 \\
\hline 禰祭 & 考妣 & 9 月 & 正寢 \\
\hline 墓祭 & 始祖以下、考泚 & 3 月 & 墓 \\
\hline 忌日祭 & 高. 曾. 祖考妣、考妣 & 忌日 & 正寝 \\
\hline
\end{tabular}

しかし、朝鮮時代を通じて、行なわれた祭祀の種類とその実行場 所は『朱子家禮』の原則のみに沿うのではなく、祭祀主によって差 異を見せる。特に、柳濟陽が父親の忌日祭を行なうため用意した場 所は、『朱子家禮』の形式に沿わず、大舎廊棟の舎廊房であったとい う点において特異である。すなわち、4 章で述べた舎廊房（歸晚窝、 隨分室) は、家事を管理する場所であるばかりではなく祭祀を行なう 場所でもあり、「正寢」注50)と呼ばれる。

○柳濟陽『是言』 1 巻、1868 年 (戊辰) 9 月 17 日 父親が亡くなって 18 年の祭祀の夜である。冠禮式後、 5 年 になる秋であり、父親の魂が必ず正寝に現れるだろう。私は 父を懷かしむ心でいっぱいである。父親の魂が息子に家を与 えるのはこの時である。だから隨分室に居ることにした 注 ${ }^{51)}$

19 世紀 (柳濟陽の時期)には内棟の内房を正寝とするのが一般的 であるが、日記では舎廊房、「隨分室」を正寝としている。つまり、 本来の場所である内棟の内房ではなく、舎廊房に正寝という語を用 いて舎廊棟の場所的位階を内棟より高めて強調している。

正寢の重要性は『朝鮮王朝実録』の記録にも明らかである。家に 祠堂や祭祀を行なう場所がない場合、正寢という語を使って中心を 表現したり 注 ${ }^{52)}$ 、王の祭祀を行うところを正寝と表現して位階の秩 序を正しく定立させたりしている注 53)。

すなわち、正寢という語を用いることで隨分室を雲鳥楼の中心と して位置づけていることになる。

\section{6. まとめ}

本研究は、住まいにおける場所の意味を究明することを目指して いる。特に、朝鮮後期の日常生活と文化の中で懸板と日記（是言・紀 語)を史料として論じ、以下のことを明らかにした。

第一、懸板の位置とその意味を通じて雲鳥楼における舎廊房の中 心性を明らかにした。舎廊房には柳爾胄がすでに「住まうべき本来 
の場所」という意味の懸板を掛けており、同じ舎廊房に柳億が重㸚 て父親の別號を用いた懸板を掛けている。すなわち、舎廊房は生活 相と家系継承の中心性を持つことが分かる。

第二、舎廊房は単純な起居の中心場所ではなく、家長の権利をと もなう空間である。家長の権利とは家事権、祭祀権であり、その実 行能力を備えなえれば舎廊房に起居できないのである。

第三、雲鳥楼の主人は「正寝」の語を用いることで家の中心を表 していた。正寢とは祭祀を行うべき場所であり、父親の霊のあらわ れるところである。したがって、雲鳥楼の中心は内棟や祠堂ではな く舎廊房とされる。

本論文では、柳氏家の史料から、彼らの日常生活の様相を明らか にすることを通じて住まいの場所の意味を究明してきた。そして、 柳氏の住まいである雲鳥楼では舎廊房が中心とされていることを明 らかにした。

今回論じた面以外にも、当時の 兩班の生活文化の中には接客や具 体的な家事の管理といった面が知られている。したがって、今後の 研究では、これらの生活文化からどのような人間と住居の関りが読 みとれるのかを論じていきたい。

\section{注}

注 1）雲鳥楼は、韓国の全羅南道求禮郡土旨面五美洞に現存している朝鮮後 期(18 世紀 1776 年) の代表的な全羅道地方の建築物であり、重要民俗 資料第 8 号 (1968 年指定)に指定された伝統上流住宅である。

注 2）韓国国立民俗博物館, 求禮雲鳥楼, 民俗博物館学術叢書 4, 1987.12

注 3）韓国文化財庁，求禮雲鳥楼，韓国の伝統家屋 21，2007. 12

注 4） 金正基 : 求禮雲鳥楼，民俗資料調查報告書第 8 号，1968.3

注 5) 朴益秀: 求禮雲鳥楼의 造営에 관한 史料的考察, 建築歷史研究, Vol . 3 No. 2, 203-214 頁， 1994.12

注 6) 朴益秀: 求禮雲鳥楼의 住宅史研究, 大韓建築学会論文集, Vol. 14 No. 2, 195-208 頁, 1998.2

注 7) 김 왕직 : 求禮雲鳥楼의 創建과 変遷에 관한 研究, 建築歴史研究, Vo 1. 17 No. 4, 181-195 頁, 2008. 8

注 8) 최수영, 他 2 人 : 全羅求禮五美洞家圖을 통해서 본 雲鳥楼의 空間構

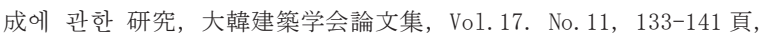
2001. 11

注 9) 박수환 : 求禮柳氏生活日記「紀語」을 통해서 본 近代生活의 一面, 国立民俗博物館, Vol. 25，1-15 頁，2004

注 10) 최만홍: 求禮雲鳥楼庭園创 관한 研究, 韓国庭園学会, Vol. 15 No. 2 ,147-154 頁, 1997. 12

注 11) 신상섭 : 求禮雲鳥楼의 造営思想에 관한研究, 韓国庭園学会, Vol. 17 No. 2, 69-78 頁, 1999.6

注 12) 정치영 : 日記를 통해서 본 韓末一日本統治時代兩班小地主의 活動 空間, 大韓地理学会, Vol. 39 No. 6, 922-932 頁, 2004

注 13）朝鮮時代の生活日記は、その性格によって様々に分類できるが、そ れらが持つ共通点は当時の現実をそのまま反映しているという点で ある。また、子孫によって再編されることも珍しい。このような理 由から日記類はほとんどが一次的な史料の性格を持っており、古文 書とともに重要な史料として価值が認識されている。ただ、日記の 特性上ほとんどが個人的な内容のことであり、そこに記録としての 限界がある。しかし、内容上複合的で多様な性格を持っている。日 記の書かれた時期的特徴を理解することにおいて、朝鮮時代の生活 日記は役に立つ史料として認められている。

注 14） *政治, 経済, 社会, 生活史関連研究

이성임 : 16 世紀朝鮮兩班官僚의 使喚과 그에 따른収入-柳希春의 眉巖日記㞯 中心으로一歴史学報, Vol.145, 91-146 頁, 1995 이성임 : 朝鮮中期인 兩班家門의 農地経営과 奴婢使喚一柳希春의 眉嚴日記을 中心으로一診断震檀学報, Vol. 80, 115-151 頁, 1995 정근식 : 默齋日記에서 나타난 家祭祀의 実態, 法制研究, Vol. 16, 229-253 頁, 1999

전연식 : 朝鮮時代의 끼니, 韓国史研究, Vol. 112，63-95 頁, 2001 *家庭管理関連研究

김성희 : 鎖尾錄에서 나타난 16 世紀家長의 役割, 家庭管理学会,
Vol. 18 No. 4, 13-24 頁, 2000

*文学関連研究

박경신 : 丙子日記研究, 国語国文学 104 巻, 157-177 頁, 1990.12 김영춘 : 丙子日記에서 나타난 17 世紀国語研究一音韻変化을 中心 으로—청어람文学, 1994

정창권 : 眉酦日記에서 나타난 宋德峰의 日常生活와 創作活動, 論 文学, 534-554 頁, 2002

*建築関連研究

이호열 : 16 世紀末士大夫 家客廳営造 事例研究一柳希春의 眉䉷 日記을 中心으로-,建築歷史研究, Vol.1 No. 2, 9-39頁, 1992.12 정정남 : 生活日記에서 본 16 世紀邑内에 位置한 住宅의 空間構成 과 活用, 大韓建築学会論文集, Vol. 19 No. 7, 133-143 頁, 2003.7 정 정남 : $16 \cdot 17$ 世紀士大夫住宅의 空間構成斗 活用, 京畿大学博士 論文，2003.12，など、書誌学，養蜂学，民俗学でも日記関連研究を 探して見ることができる。

注 15）雲鳥楼が位置した土旨面という名前は金指輪を吐くという意味の「吐 指」と言われており、これは多産と生産を意味する。このような形 勢を村の人々は「神様が口にかんでいた金指輪を叶いて置いた所」 すなわち、金環落地の姿で豊かな富貴栄華が泉のように乾かない明 堂と言っている。

注 16）韓国国立民族博物館，前掲書， 26 頁，1987. 12

注 17）李重煥著, 李翼成訳：擇里志，을류文化社，86 頁，1993.10, 求禮の 西方は鳳洞であり、珍しい泉石で知られる。東には華嚴寺と燕谷寺 の名勝があって、南側は九萬村がある。任實から求禮まで江にそっ て下ると、有名な地域とみごとな景色が多く、また大きな村が多い。 その中でも九萬村は川のほとりに臨み、江山の土地と川舟を通じて 得る魚や塩などの利益があって、最も住むに適した場所である。「求 禮西有鳳洞, 泉石之奇。東有華嚴燕谷之勝, 南則営九灣村自。任實 至求禮沿江上下多名區勝稆，又多大村塢惟。九灣臨溪水上江山土地

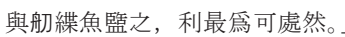

注 18）雲鳥楼の卜居初期から伝えてきた風水説、明党説などによって金環、 歸晚 (柳爾胄の別號)、九萬(現在の土旨面の所在地) という別称は同 じ場所の意味に解釈されている。

注 19）村山智順：朝鮮の風水，朝鮮総督府，846-849 頁，1931，秘記に所謂 「金龜没泥」「金環落地」及び「五寶交聚」の三つの眞穴があり、(以 上三つを上台、中台、下台と伝ひ、下台が最吉とされてるる。）それ を尋祇あて其處に家を建て住めば、勞せずして天運の幸するところ となり富貴笨達は意のままであると云ふ信仰からである。からした 信仰を裹書した事證として此地きつての舊家である柳氏の宅が五美 里にある。この宅地は柳氏現主の遠祖柳富川と云ふ人が今から三百 年程前に卜居したものであり。この富川と云ふ人は李氏倒壊を企て 其處から京城まで毎夜雲に乗つて往復した程の方術に通じた者であ つたので、良き風水を相して家の礎石を定めんとしたところ、圖ら ずも其處から龜石が出土した。そこで秘記に所謂る金龜没泥の地は 正しく此の地である事がたしかめられ、爾來柳氏は繁㮡をつづけて 今に土地一番の豪家であり資産家となつて居る事である。(この出土 した龜石、郎ち秘記に所謂る金龜没泥の金龜は現に柳氏の家寶とし て重藏されて居る。それは大きさ兒頭大の龜形をした石塊で、これ を入れてある箱蓋には「崇視紀元後三丙卯年五美洞瓦家開基時所出 石云耳。壬戍五月十一日乙已書」と書してある。

注 20） 1767 年水禦廳把摠城機別將 (南漢山城女堞築造), 1768 年南道兵㲊候, 1771 年樂安郡守, 1773 年三水流配 (1774 年解ける)，１776 年咸興城 役後嘉善大夫五衛將，1777 年尚州營將，1782 年龍川府使，1786 年 慶尚中軍 (營城築造), 1789 年三水府使・水原中軍(園役), 1791 年資 憲大夫豊川府使を歴任。韓国国立民族博物館, 前掲書, 32 頁, 1987. 12

注 21）尹師國編：三水公行壯，〈前略〉風水説に明るく、その知恵によ って求禮の歸晚 (現在の五美洞：歸晚と金環、九萬は同じ地名 に見ている)に占いを行って住居を決めた。そして、三水の流 配地から戻ってきて兄 (爾惠) と家族をみんな連れて、この異郷 に行った。人々が五美洞の土地を吉地だと言うが、険しい土地 で栄えず、昔の人は思い切って占有することがなかった。公が 笑って言った。「天はこの地を大切に思い、この地を隱して私 を待っていたのだ。」と数百人の人夫を動員し、その日のうち に家の土台ができた。また四寸弟(爾翼)を迎えて、隣りに家を 建てて、村落を成寸上うになった。「前略〉事務方技多所通曉 於堪興家亦知其略見求禮之歸晚, 意欲卜居自。三水謫環奉名吉 地畫室而往異鄉無與助。大度地經始屋百餘間人言此基素名吉地 嚴險難爲力故人莫敢占矣。公笑日天慳地柲其待我也役用數百丁, 不而基成又邀其從弟傍営之家自成一聚落乃日家居踓眞若使 之不免飢寒豈邀欲同居之意〈後略〉」 
注 22) 雲鳥楼の規模変化に対する研究は、朴益秀: 求禮雲鳥楼의 造営 에 관한 史料的考察, 建築歴史研究, Vol. 3 No. 2, 203-214 頁, 1994.12 と求禮雲鳥楼의 住宅史研究, 大韓建築学会, Vol. 14 No. 2，195-208 頁，1998.2によって進められた。

注 23）家屋の規模は、1793 年柳爾胄が 68 歳の時、彼の息子に財産を分ける 際の記録である分財記から分かる。祠堂二間，體舎九間，東翼廊三 間 (層樓四間), 西翼廊三間 (層樓三間), 前行廊六間, 中外舎三間, 外舎八間，東行廊十二間，下外舎四間，大門一間，西挾廊三間，東 足砧舎三間，西行廊十二間，内・外則二間 として総 78 間の規模に なり、建立当時と同一な原型的規模である。韓国精神文化研究院： 求禮文化柳氏篇 2、古文書集成三十八，25 頁，1998，また、家屋の 形態は、求禮五美洞家圖 (1800 年前・後推定) と五美洞瓦家舊時全圖 (1916 年)を通じても確認できる。

注 24）雲鳥楼の現場調査と実測は、2010 年 2 月 27 日と 29 日の両日間にか けて行なわれた。

注 25）五美洞瓦家舊時全圖は1916 年柳濟陽の家屋重修記に添付された雲鳥 楼の平面図であり、全体建物の構図を一目で見ることができて、家 屋の平面と規模、建物の存廃現況を数值で表示したものである。求 禮雲鳥楼所蔵。

注 26）雲鳥楼の創建主から彼の 6 代孫に至るまで自分の別號を使用・製作 することで家内の方々に付着されている。

注 27）柳濟陽の「是言」は、1851 年から 1922 年まですべて 72 年間の記録 として 7 巻 5 本で構成されている。

注 28）柳瑩業の「紀語」は、1898 年から 1936 年まですべて 39 年間の記録 として 38 巻 31 本で構成されている。

注 29) 柳營業「紀語」 15 巻 1913 年(癸丑) 5 月 4 日、祖父は始めて私に五石 という號を授けた。この五石の二文字は、深い意味から出たもので ある。昔、私の 6 代前の祖の三水公(柳爾冒)が官職をやめてこちら に田畑を開いて家を建て、五美と名付けてから 130 年である。今私 の號である五石の五の字は、五美洞の五の字から出たのである。「祖 父主始命余以賜号曰五石。二字出於重本中來矣。昔我六代祖考三水 公解組投印, 開庄于此地且建築家舎洞以名五美于今百有數三十餘年 也。而余今為之号曰五石，五一字出於五美洞中五字。」

注 30）柳禜業「紀語」 24 巻 1922 年(壬戌) 4 月 26 日, 高祖である圓石公と 古東先生は親交があり、家の足閒亭・雲鳥楼・隨分室・歸來亭の懸 板はすべて古東先生の真筆である。また、二肯齋・歸晚窩・湛樂窩 の懸板は、尹師國の真筆で、彼は 6 代祖三水公と同僚であり、若き 時より友人で三水公の行狀も作った方である。「古東先生与我高皇考 圓石公, 有契分之深而家之足閒, 雲鳥, 隨分, 歸來諸扁蒼并皆古東 眞跡也。二肯, 歸晚, 湛樂諸扁食亦尹師國親墨也。尹負相与我六代 祖考三水公同僚，而自微少時知己故三水公行狀所著者」

注 31）柳濟陽「是言」 2 巻 1899 年 (己亥) 10 月 7 日，二山楼の懸板を閔泳喆 が刻んで送って掛けた。「二山樓閔台泳喆刻板二樓懸板送來」

注 32） 懸板の位置は、柳爾冒の 10 代孫である柳鴻洙 (1954 年〜) 氏からの聞 き取り調査と、先行研究 (韓国国立民俗博物館、「求禮雲鳥楼」, 民俗 博物館学術叢書, 51 項)によって把握した。

注 33）柳瑩業「紀語」 12 巻 1910 年(庚戌) 11 月 22 日, 公は、求禮の歸晚の 意味をみてト居して歸晚と言おうとした。これは九萬である。歸晚 と九萬は音がほぼ同じで、前坪の大野も九萬坪と呼ばれる。三水公 は自號を歸晚窩とつけたこともこのような地名に応じたのである。

「公見求禮之歸晚意, 欲卜居云此歸晚師九萬也。歸晚与九萬音畧相 同，而前坪大野通名九萬坪。云三水公自号歸晚窩恐意應地名取」

注 34）供亨沃：韓国住居史，民音社，155 頁，1992.8

注 35）供亨沃: 前掲書, 142 頁，1992.8，供亨沃は韓国伝統家族家の系継承 方法を東南型 (隠居型)、西部型 (終身型)、濟州型(独立型)、咸鏡道 型(再帰型)の四つに分類し、詳しく説明している。

注 36）高麗大學校民族文化研究所編 : 韓國民俗大觀, 1 巻社会構造・冠婚喪 祭，高大民俗文化研究所， 685 頁，1980.10，韓国で祭祀の概念が普 遍化され始めたのは中国儒学の影響を受けた後である。具体的には 高麗末期、仏教の勢力が弱くなった時期にあたる。すなわち、仏教 に対する反対勢力として歴史的・政治的な背景を持って活発に伝播 または普及され始めた時期をいう。

注 37）高麗大學校民族文化研究所編: 前掲書, 377-378 頁, 1980.10, 韓国の 家父長制度は、嫡子直系の血縁を基盤にする家系継承を重要視し、 家系を継承する長男は祭祀の義務と責任を負うようになる。

注 38）柳濟陽「是言」 1 巻 1851 年 (辛亥), 哀我生六歳。孤略不省先考府君 顔髪而懓然憶朱顔華髮身之頎然焉爾矣。

注 39）柳濟陽「是言」 1 巻 1862 年 (壬成), 誦詩於二肯齋。無師友治功令詩 間嘗作近體看。漢魏唐宋諸大家詩。辛西春重修外舎之前東西長行廊 二十餘間東西毁撤四間。迄于秋竣役時季父管家事。
注 40）柳濟陽「是言」 1 巻 1868 年 (戊辰)，戊辰秋居隨分室始理家事。隨分 室曾王考別號。

注 41）神主は日本の位牌にあたる。

注 42） 柳濟陽「是言」 1 巻 1869 年 (己巳)，茶禮祠堂己巳元朝，高曾祖考泚 神主各合讀，而先考府君未之既成者在辛亥秋，先考喪葬之日，兒年 六歳，未克主祀，而巨創蒼黄，垧事者又不嫺禮可恨，然而世故漸多 因循日，不肖兒恨毎於忌日名節以紙榜行祀，自責無誠追成神主，禮 無早晚焉爾。

注 43）朝鮮時代の家系は、代々長男によって継承されることになっていた。 つまり、雲鳥楼の柳氏家の家系継承は、柳濟陽 $(1846 \sim 1922)$ から柳

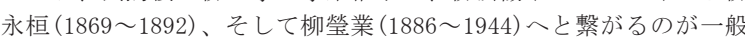
的である。しかし実際は、柳濟陽から柳營業へ家系が継承された。 その理由は、柳永桓が 23 歳という若い年齢で死亡したということに あり、そのために柳濟陽は、柳永桓の長男である柳瑩業に家系を継 承させたのである。

注 44）柳濟陽「是言」 19 巻 1917 年 (丁巳) 1 月 24 日，十有一年，鎖閉門房 世故如何滿目滄喿〈中略〉家孫稍壯溜掃室堂, 非余之志曷云無妨。二 四日丁巳隨分室改堗入処。

注 45）歲拜 (セべ) は、韓国の旧正月の朝に礼を執り行った後、目下の人が 目上の人に礼をして、新年の挨拶をすることを言う。

注 46) 柳瑩業「紀語」 34 巻 1932 年 (壬申) 1 月 1 日, 歲拜場所, 大舎廊隨分 室臨時使用, 而余自昨冬方此住於歸來亭

注 47）柳瑩業「紀語」 35 巻 1933 年(癸西) 1 月 1 日，早朝入祠堂但納拜而, 使呚兒等替行茶禮

注 48）柳營業「紀語」 35 巻 1933 年(癸西) 1 月 14 日，曾祖妣鎮川宋忌日也 中略>呚兒送雲川省掃

注 49）考泚は亡くなった父母のことを意味する。

注 50）正寝は、祭祀を行なう母屋の部屋又は仕事をするのに使う母屋の部 屋。つまり、空間の位階を高めて呼ぶ言葉であり、建物の中心にな るところを意味する。大阪外国語大学朝鮮語研究室編、『朝鮮語大辞 典』、下巻、2084 頁、角川書店 1986

注 51）柳濟陽「是言」 1 巻 1868 年(戊辰) 9 月 17 日, 戊辰九月十七日, 即府 君下背世後十八年忌祭入齊之夜也。兒冠後五年秋也，則府君之神霊 必著於正寝。兒風樹感慕何極哉。府君之靈以家界兒必乎時也。故目 居隨分室。

注 52) 朝鮮王朝実録、英祖 58 卷，19 年 (1743 癸亥・乾隆) 8 年 6 月 20 日 (幸 未)，元景夏の話を聞けば、吳瑗の家にも祠堂がなく、公主の神主を 正寝に奉於したと言うので、公主の祠堂を建てる時には該曹にその 費用補助させた。「今聞元景夏言, 吳瑗家亦無祠, 公主神主奉於正寢, 云公主祠宇營建時, 亦令該曹助其費」

注 53）朝鮮王朝実録，英祖実録(付録)，英祖大王哀冊文，慶熙宮の正寝で 夢去し、この年の秋 7 月庚午朔 27 日丙申に元陵へ永遷した。禮で ある。「荳于慶熙宮之正寢, 是年秋七月庚午朔二十七日丙申, 永遷于 元陵。禮也。」哀冊文は、王や王妃の死を哀悼しながら作った文であ り、英祖王以外の王の哀冊文でも『正寢』の記録をみることができ る。

\section{参考文献}

1）韓国精神文化研究院: 求禮文化柳氏 生活日記, 韓国学資料叢書二十八, 2000

2）韓国精神文化研究院: 古文書集成三十七・八，求禮文化柳氏篇 $1 \cdot 2,1998$

3）韓国国立民俗博物館：求禮雲鳥楼，民俗博物館学術叢書 4, 1987.12

4）韓国文化財庁：求禮雲鳥楼, 韓国의 伝統家屋 $21,2007.12$

5）韓国農村経済研究院：求禮柳氏家手 生活日記上・下，農村 吕 農業構造 変遷関係資料 $1 ， 1991$

6）雲鳥楼：全羅求禮五美洞家圖，図版，1800

7) 雲鳥楼：五美洞瓦家舊時全圖, 図版, 1916

8）村山智順：朝鮮の風水, 朝鮮総督府, 1931

(2011年 7 月 4 日原稿受理，2012年 1 月 23 日採用決定） 